University of Michigan Law School

University of Michigan Law School Scholarship Repository

2002

\title{
The Constitution and the New Deal
}

Richard D. Friedman

University of Michigan Law School, rdfrdman@umich.edu

Available at: https://repository.law.umich.edu/reviews/12

Follow this and additional works at: https://repository.law.umich.edu/reviews

Part of the Legal History Commons, and the Supreme Court of the United States Commons

\section{Recommended Citation}

Friedman, Richard D. Review of The Constitution and the New Deal, by G. E. White. Mod. L. Rev. 65, no. 5 (2002): 805-9.

This Review is brought to you for free and open access by the Faculty Scholarship at University of Michigan Law School Scholarship Repository. It has been accepted for inclusion in Reviews by an authorized administrator of University of Michigan Law School Scholarship Repository. For more information, please contact mlaw.repository@umich.edu. 
As she has not done that, the chapter provides little reason for her readers to agree with the conclusions she reaches.

So, where does that leave Biggs' Euthanasia, Death with Dignity and the Law? As a discussion of the current state of the law, it is fairly successful. It is also successful at showing the difficulties of the current state of the law and its lack of coherence within health care law. For these two reasons, it will provide a useful research tool. However, it does not provide a convincing argument about how the euthanasia debate should be resolved. Autonomy is a difficult concept to grasp, especially within the context of medical decision-making, and dignity is an inherently subjective determination. Any discussion of these issues, therefore, needs to provide some system for analysis; otherwise, the discussion will fail to convince anyone not already predisposed towards the author's views. Since Biggs' book does not provide such an analysis, the overall result is a disappointment.

Stephen W. Smith*

G. Edward White, The Constitution and the New Deal, Cambridge, MA and London: Harvard University Press, 2000 , xii +385 pp, hb $£ 32.95$, pb £13.95.

The Supreme Court of the New Deal era continues to captivate American lawyers and historians. Constitutional jurisprudence changed rapidly during the period. Moreover, some of the most significant changes appeared - whatever the reality to result from pressure imposed in 1937 by President Franklin Roosevelt's plan to pack the Court with Justices amenable to his programme. The structure of constitutional law that emerged within a few years of Roosevelt's death remains intact in significant respects today.

The New Deal period therefore presents significant issues of continuing interest: How does constitutional law change, over the short and long runs? To what extent are Supreme Court Justices' decisions subject not only to their own ideological orientations but also to political pressures of the type that are ordinary imposed on the other branches of government - and to what extent should their decisions be subject to such pressures?

Professor G. Edward White, one of the United States' most distinguished legal historians, has contributed to this discourse with his thoughtful book, The Constitution and the New Deal. Some readers may be perplexed to find that substantial portions of the book do not deal with the Constitution, that much of it does not concern the New Deal, and that only relatively small portions of it address constitutional issues that were particularly salient during the New Deal. But the book is very much about setting a context, and part of White's point is that the importance of the New Deal as an engine driving constitutional change has been considerably overrated.

As White explains, the conventional account of early twentieth-century constitutional history characterises the New Deal 'as the source of a new era of constitutional law and constitutional interpretation, in which the Constitution was adapted to facilitate a new realm of American governance' marked by affirmative roles for state and federal governments as regulators of the economy and as distributors of economic benefits ( $\mathrm{p} 3$ ). This new realm anticipated a new role for judges, in which they accorded considerable leeway to the political branches in

* PhD candidate, University of Manchester. 
exercising these regulatory and distributive functions, but at the same time carefully scrutinized laws and policies that might infringe on rights and liberties 'deemed foundational to a modern society.' (pp 3-4). In the conventional account, Roosevelt's landslide history in 1936 and the Court-packing plan of the following year are perceived as being instrumental in causing dramatic constitutional change (p 14). Thus, in one modern version of the conventional account, Bruce Ackerman presents 'a radical discontinuity between the decades that preceded the New Deal and the New Deal itself,' which 'helps highlight the New Deal's transformative character' (p 27).

White contends that the causal relationship between doctrinal changes in constitutional law and the New Deal 'was far more complicated, and attenuated, than existing scholarship has suggested.' In some areas change was under way long before the New Deal period, and was not resolved until later. And the development of the Court's posture of bifurcated review also occurred over a far longer period than has usually been supposed ( $p$ 4). Furthermore, events of the early twentieth century have been seen so much through the perspective of the New Deal that juridical perspectives that were perfectly respectable in the earlier time have since been pilloried, as have the Justices who advocated them (pp 14-15, 269-270, 288-291).

To a large extent, I agree with White. We should do away with the oft-used term 'constitutional revolution of 1937'. Perhaps the transformation in constitutional law that occurred during the 1930 s and 1940 s constituted a revolution; as White recognises (p 199), it was broad, deep, and, in historical terms, rapid. And in 1937, in the shadow of Roosevelt's re-election and the Court-packing plan, the Court issued several significant decisions that were key parts of that transformation. But they were far from the whole story, they had significant pre-plan antecedents, and there is no persuasive evidence that they were caused by the politics surrounding Roosevelt's initiative.

I agree, moreover, with White's principal historiographic conclusion: The persistence of belief that political factors must have caused the Court's 1937 decisions is a puzzle to which a crucial key is the widely held belief among many academics that Justices are basically political actors subject to ordinary political forces. White is correct, for example, that Laura Kalman's intellectual presuppositions prevent her from 'giv[ing] much credence to a theory of constitutional change that appears to minimize the deeply behavioral character of judging and the apparently inevitable tendency of constitutional law to become subsumed in politics'. From the perspective of many scholars like her, "to emphasize the role of established legal ideas and doctrines as causative factors is to invite the revival of an older, unreflective caricature of judging as an apolitical process' ( $p$ 31).

In considering White's stance and contribution, it might help to bear in mind the attempts by Kalman and others to distinguish 'between internalists, who point to doctrinal, intellectual causes in explaining constitutional change during the New Deal, and externalists, who stress political reasons'. (Kalman places me in the internalist camp). To my mind, the dichotomy is a false one. On the one hand, if we want to understand constitutional change we must pay attention to doctrinal constraints; to assume that constitutional law is nothing but a reflection of the various political, intellectual, and social forces swirling through society would ignore the reality that at any given moment the Justices' plausible options are significantly constrained by the web woven by prior decisions. On the other hand, it would be equally unrealistic to ignore those forces and treat the Court as if it were hermetically sealed from the outside world. Indeed, the chief generator of constitutional change is probably created by the closest interface the Court has with the external, political world - the appointment of new Justices. We must ask what external forces affected 
the Court in a given era, and how. To conclude that a given set of political pressures had no discernable effect on the Court in a given era is not to conclude that political factors are not worthy of attention in trying to explain constitutional change.

White helps bridge the gap between internalist and externalist explanations. Put another way, he pays attention, appropriately, to both internal and external forces. He treats doctrine seriously, and much of the book concerns doctrinal change in constitutional and non-constitutional law in the first half of the twentieth century. At the same time, he places those changes in the broad social context of modernism, 'a distinctive consciousness that has shaped the responses of Americans to their encounters with modern life'. As he uses the term, modernism is reflected in 'an attitude that elevates human agency, as distinguished from potent external forces, to a position of causal primacy in the universe, and thus takes for granted that humans are capable of controlling their environment and shaping their collective destinies' ( $p$ 5).

After outlining the conventional account and its modernist underpinnings, White begins by examining three areas that, as he says, 'lie on the periphery of the conventional narrative's focus' - the constitutional law of foreign affairs, administrative law, and free speech. He does so, he says, because by showing that the law in all of these areas changed substantially and relatively gradually before the New Deal era or the Court-packing crisis, he "hope[s] to engender an attitude of skepticism toward the conventional account's treatment of its central areas of concern' ( $p$ 12). In terms used by his colleague Barry Cushman, his aim is to create sufficient intellectual space for an alternative account.

It is all very well to show that in various doctrinal areas the law changed gradually and substantially before the crisis of the 1930s, and White does a fine job of showing that it did. But this is not particularly surprising, and as long as one remains on the periphery of the issues that were most pressing during the crisis it is hard to get much of a handle on the question that is of chief interest: Why did the Court make - or at least give the appearance of making - such a dramatic shift on those issues after Roosevelt issued his plan? To answer that question, one must delve into the cases actually dealing with those issues.

White moves towards the heart of the matter in a chapter on the formation of the American Law Institute (ALI) and the launching of its Restatement project. Drawing on but adjusting Langdellian orthodoxies of the late nineteenth century, the ALI founders 'separate[d] the essentialist authority of the black letter principles being compiled by authors of Restatement volumes from the expertise-based authority of the compilers' ( $p$ 181). The premise that such a separation was possible exposed the ALI to modernist-inspired criticism from the Legal Realists, who contended that the whole project was incoherent, failing to recognise the importance of human agency in the development of law. To a typical Realist, 'science' in law 'was contextual rather than conceptual, behavioral rather than taxonomic' ( $p$ 191).

The same debate, as White shows, played out in the constitutional context and accounts in large part for the commitment of many scholars to the view that the Court-packing crisis played a critical role in leading to the constitutional transformation of the1930s and 1940s. The conventional account, taking the Realist perspective, accepts a 'behavioralist view of judges as constitutional interpreters' and 'rejects, as antiquated or misguided, any conception ... that treats the authority of the Constitution's text as separate from the authority of those given the power to interpret it' (p 200). This account is, he says, a 'triumphalist narrative', (p 237) for in the 1930s 'the proposition that judges, in their role as constitutional interpreters, made law in the legislative sense ... worked its way from the status of critique to something approaching orthodoxy' (pp 234-235). Thus, in an interesting and useful twist, he 
sees the Court-packing crisis not as a cause of revolution but 'as a product of a constitutional revolution, one whose revolutionary character was far deeper and wider than any "switch in time"" (p 235).

The argument is a valuable one, but I believe White takes it too far, and in two directions. Before the $1930 \mathrm{~s}$, the role of judicial ideology in determining constitutional law was well understood. And the Justices who actually effected the constitutional transformation of that era did not view themselves as unconstrained by prior law.

There probably never was a time when the impact of ideology on the Justices' shaping of constitutional law was not well understood, at least by attentive observers. Consider two statements that have become cliches, both dating to the first decade of the twentieth century. '[N]o matther whether th' constitution follows th' flag or not,' the fictitious Mr Dooley said in 1901, 'th' supreme coort follows th' iliction returns.' And six years later, the Republican Governor of New York, Charles Evans Hughes, declared, 'We are under a Constitution, but the Constitution is what the judges say it is ...' Nominations to the Supreme Court in the years surrounding the Civil War frequently aroused fierce, ideological opposition. By the early years of the twentieth century, as the great issues that had divided the nation receded, the process had generally become more routine - but not always. Mahlon Pitney in 1912, and Hughes and John J. Parker in 1930, faced significant, ideologically based, opposition from the left - in Parker's case, enough to defeat his nomination, based on the perception that he was racist and anti-labour. Opposition to nominees was not limited to insurgents. The 1916 battle over Louis Brandeis (barely mentioned by White, and only in another context) was, with the possible exception of the one over Robert Bork in 1987, the hottest and most ideological nomination contest of the century. The resistance to Brandeis came from the right, was deeply ideological, and was led by pillars of the legal establishment. And conservative Justices like William Howard Taft and James McReynolds constantly worried about the impact of more liberal judges.

But to say that ideology matters is not to say that it is all that matters. Indeed, the most genuinely realist view, while recognising that a Justice is not completely constrained by text and precedent, does not fail to recognise that these factors have considerable force. Whatever some commentators might say, the Justices themselves have never treated doctrine as if it counted for naught. Thus, I believe White goes too far in saying that 'the Supreme Court justices themselves ... concluded that there was no intelligible distinction between the authority of legal sources and that of their designated interpreters'.

Consider, for example, the following statement by Justice Roberts, one of the most notorious articulations of that distinction but - surprisingly, especially given that he analyses numerous texts at length - one that White never addresses:

When an act of Congress is appropriately challenged in the courts as not conforming to the constitutional mandate, the judicial branch of the government has only one duty; to lay the article of the Constitution which is invoked beside the statute which is challenged and to decide whether the latter squares with the former. All the court does, or can do, is to announce its considered judgment upon the question ... This court neither approves nor condemns any legislative policy. Its delicate and difficult office is to ascertain and declare whether the legislation is in accordance with, or in contravention of, the provisions of the Constitution; and, having done that, its duty ends.

Roberts included this passage in one of his most rightward-looking opinions, United States v Butler (1936). But it must be remembered that he was a key player in the constitutional transformation. In Home Building \& Loan Association v Blaisdell (1934), which White appropriately uses to show the clash of modes of interpreting 
the Constitution, Roberts had provided the critical vote favoring Hughes' modernist opinion over Sutherland's traditionalist one. He had written the distinctly modernist Nebbia v New York (1934), a critical decision that rejected the doctrine that there was a 'closed class or category of businesses affected with a public interest' that could be subjected to price regulation. He joined the liberal majority in all the great cases during the climactic spring of 1937, and signed on with no more apparent hesitation than any other member of the Court to the pair of cases that consolidated the development of Commerce Clause doctrine, United States v Darby (1941) and Wickard v Filburn (1942). Thus, the Butler passage in which he expresses quite clearly a separation between the sources of law and its expositors must be regarded not as the ravings of a traditionalist detached from reality but as a reflection of the ambivalence and tension felt by a real judge respecting the force of doctrine even as he helped to reshape it.

Consider also Justice Jackson, the author of Wickard. Drawing on work by Cushman, White invests Wickard with great significance. Wickard, by holding that Congress could regulate the amount of wheat consumed on the farm, pushed Congress's power to regulate commerce quite far - though not unreasonably, in my view. It is also true that Jackson, a judge who reveled in second thoughts, mused about taking the position that 'the commerce clause is what the Congress says it is' ( $p$ 231). But the opinion he actually wrote for the Court said and did no such thing. He reviewed the course of precedent with respect, and applied a flexible doctrinal test that had strong roots in opinions dating to the early part of the century. He did not try to detach the scope of federal powers from the language of the Commerce Clause and, though for the following half century the Court never held that Congress had overextended its reach under the Clause, even during that era Congress, legislatures, and courts always felt the need to establish a relationship between the activities being regulated and interstate commerce. Moreover, a doctrine of extreme judicial selfabnegation, which is what the Commerce Clause cases culminating in Wickard established, hardly reflects an attitude that the expositors of the law are fully in control of it. On the contrary, by according Congress quite a free hand, these cases narrowly confined the power of the courts, and that is probably a large part of the reason this doctrine remained remarkably stable for more than fifty years.

White says that one of his aims is to 'complicate' the conventional account of constitutional change in the New Deal era ( $\mathrm{p}$ 12), and he has succeeded. He lends considerable weight to those who resist the seductive political account of the great constitutional transformation. He argues forcefully that the conventional account 'has been an exercise in "winners' history"' ( $\mathrm{p} 308$ ), and he presents the interesting hypothesis that, though the New Deal represents 'the midpoint of a crisis in early twentieth century American jurisprudence,' it 'had its own parochial flavor and its own discrete constitutional issues, which can be seen as distinct from, and not in themselves more significant than, the constitutional issues that were central to the 1920 s or to the 1950s' ( $p 310$ ). Yet, to gain a fuller understanding of the sea change that occurred in the years surrounding 1937, one must complicate the account even more. It is not enough to consider the political, intellectual, and even doctrinal context in which the Court worked. One must also delve deeply into each of the significant cases, attempting to determine the combination of doctrine, politics, ideology, temperament, and idiosyncracy that led each of the nine men who constituted the Court to act in the way he did.

Richard D. Friedman*

* University of Michigan Law School.

C The Modern Law Review Limited 2002 